\title{
Increased Glucose Disposal after Jejuno-Ileostomy
}

\author{
J. F. Rehfeld, K. B. Lauritsen, and J. J. Holst \\ Institute of Medical Biochemistry, University of Aarhus, Department of Surgical Gastroenterology, Hvidovre Hospital, \\ and Institute of Medical Physiology C, University of Copenhagen, Denmark
}

Summary. Nine patients were studied $1.5-3$ years after jejuno-ileostomy for obesity by an intravenous glucose infusion technique designed to imitate blood glucose concentrations after glucose ingestion. Whereas serum insulin and gastrin concentrations were normal, blood glucose concentrations were significantly depressed compared to preoperative levels as well as to levels in matched normal subjects. Thus, in the fasting state mean concentrations ( \pm S.E.M.) of blood glucose, serum insulin and gastrin in the patients were, respectively, $3.3 \pm 0.2 \mathrm{mmol} / 1,95 \pm$ $22 \mathrm{pmol} / 1$ and $38 \pm 4 \mathrm{pmol} / 1$. The corresponding concentrations in the matched normals were $4.3 \pm$ $0.2 \mathrm{mmol} / \mathrm{l}, 70 \pm 18 \mathrm{pmol} / 1$ and $39 \pm 6 \mathrm{pmol} / \mathrm{l}$. The glucose concentrations in the patients were low in all situations, i. e. in the fasting state, after oral glucose ingestion and during the intravenous glucose infusion. The results indicate that jejuno-ileostomy in obesity greatly facilitates peripheral glucose disposal. The mechanism behind this phenomenon is not yet known.

Key words: Obesity, glucose tolerance, hypoglycaemia, jejuno-ileal bypass, insulin, insulin antagonist, gastrointestinal hormones, gastrin, glucagon, gut-GLI.

Shortly after rediscovery $[1,2]$ of the effect of gastrointestinal hormones on insulin secretion, an effect originally named incretin [3] and later entero-insular axis [4], Perley and Kipnis suggested [5] that incretin played a major role in the hyperinsulinaemia and hyperglycaemia of obesity and maturity-onset diabetes.
In order to further elucidate the incretin mechanism we have studied the incretin-effect of gastrin in normal subjects [6-9] and in patients with disorders in the upper gastrointestinal tract [10-12]. The studies have now been extended to patients treated by jejuno-ileostomy for obesity.

\section{Patients and Controls}

Nine patients were investigated after an end-to-side jejuno-ileostomy for obesity, preserving $37 \mathrm{~cm}$ of jejunum (measured from the ligament of Treitz) and the distal $12 \mathrm{~cm}$ of ileum. The interval between operation and investigation varied from 18 to 35 months (mean 25 months). The weight of the patients was stable at the time of investigation. The data of the patients are shown in Table 1 , which also includes preoperative basal blood glucose and serum insulin concentrations [13]. The results from the patients were compared to those of nine non-obese normal subjects, matched in respect to age, height and sex (Table 1). Evaluated by the oral $50 \mathrm{~g}$ glucose tolerance test all control subjects had normal glucose tolerance. Both patients and controls gave informed consent. The patients had previously been studied ten days before and at short intervals after the bypass operation [13], using tests unsuited to the present study. As dietary supplements the patients received calcium-carbonate and vitamin $\mathrm{B}_{12}$. Neither patients nor controls received any drugs at the time of investigation.

\section{Methods}

\section{Investigative Procedure}

All patients and normal subjects were on a diet containing $250 \mathrm{~g}$ carbohydrate per day for three days before each test. After an overnight fast $50 \mathrm{~g}$ glucose as a $25 \%$ solution flavoured with lemon was given orally (OGTT). Blood samples were collected from a cannula inserted into an antecubital vein. The samples were drawn 10 and $15 \mathrm{~min}$ before the glucose loading and 5, 10, 15, 20, 30, 40, $50,60,90,120,150$ and $180 \mathrm{~min}$ after. Sera were stored at $-20^{\circ} \mathrm{C}$ until assayed. One week after the oral test each subject was submitted to an intravenous glucose infusion test (IVGI) specifically designed to study the incretin mechanism by imitation of 
Table 1. Data on patients treated with jejuno-ileostomy for obesity and on control subjects

\begin{tabular}{|c|c|c|c|c|c|c|c|c|c|c|}
\hline \multirow[t]{2}{*}{ Sex } & \multirow[t]{2}{*}{$\begin{array}{l}\text { Age } \\
\text { (yrs.) }\end{array}$} & \multirow[t]{2}{*}{$\begin{array}{l}\text { Height } \\
\text { (cm) }\end{array}$} & \multirow{2}{*}{$\begin{array}{l}\text { Weight } \\
\text { before } \\
\text { operation } \\
(\mathrm{kg})\end{array}$} & \multirow{2}{*}{$\begin{array}{l}\text { Weight } 6 \\
\text { months } \\
\text { before } \\
\text { investiga- } \\
\text { tion } \\
(\mathrm{kg})\end{array}$} & \multirow{2}{*}{$\begin{array}{l}\text { Weight at } \\
\text { time of } \\
\text { investiga- } \\
\text { tion } \\
\text { (kg) }\end{array}$} & \multirow{2}{*}{$\begin{array}{l}\text { Ideal body } \\
\text { weight at } \\
\text { time of } \\
\text { investiga- } \\
\text { tion } \\
(\%)\end{array}$} & \multicolumn{2}{|c|}{$\begin{array}{l}\text { Basal blood glucose con- } \\
\text { centrations } \\
(\mathrm{mmol} / 1)\end{array}$} & \multicolumn{2}{|c|}{$\begin{array}{l}\text { Basal serum insulin } \\
\text { concentrations } \\
\text { (pmol/l) }\end{array}$} \\
\hline & & & & & & & $\begin{array}{l}\text { Pre- } \\
\text { operative }\end{array}$ & $\begin{array}{l}\text { Post- } \\
\text { operative }^{\mathrm{a}}\end{array}$ & $\begin{array}{l}\text { Pre- } \\
\text { operative }\end{array}$ & $\begin{array}{l}\text { Post- } \\
\text { operative }\end{array}$ \\
\hline \multicolumn{11}{|l|}{ Patients: } \\
\hline$F$ & 35 & 170 & 129 & 81 & 81 & 123 & 5.9 & 3.3 & - & 48 \\
\hline $\mathbf{M}$ & 37 & 172 & 106 & 73 & 75 & 110 & 5.7 & 2.9 & - & 63 \\
\hline$F$ & 51 & 172 & 122 & 81 & 87 & 130 & 5.1 & 3.7 & 55 & 110 \\
\hline $\mathbf{M}$ & 19 & 183 & 152 & 122 & 124 & 164 & 6.2 & 2.9 & 283 & 83 \\
\hline $\mathbf{M}$ & 28 & 174 & 133 & 75 & 70 & 100 & 4.2 & 4.0 & 69 & 7 \\
\hline $\mathrm{M}$ & 42 & 178 & 150 & 111 & 107 & 148 & 12.6 & 3.3 & 290 & 60 \\
\hline $\mathrm{F}$ & 33 & 160 & 179 & 124 & 130 & 220 & 6.0 & 2.9 & 200 & 96 \\
\hline $\mathrm{M}$ & 27 & 186 & 174 & 126 & 125 & 160 & 4.9 & 3.0 & 241 & 154 \\
\hline $\mathrm{F}$ & 35 & 167 & 150 & 132 & 134 & 211 & 12.9 & 3.5 & 290 & 238 \\
\hline$\overline{\mathbf{x}}$ & 34 & 173 & 144 & 103 & 104 & 152 & 7.1 & 3.3 & 204 & 95 \\
\hline \multicolumn{11}{|c|}{ Controls (mean): } \\
\hline $4 \mathrm{~F} / 5 \mathrm{M}$ & 35 & 171 & 64 & - & - & 96 & 4.3 & - & 70 & - \\
\hline
\end{tabular}

a At time of investigation

the changes in blood glucose concentrations measured during the OGTT [8]. One third of the oral dose, $16.7 \mathrm{~g}$ glucose, in concentrations from 33 to $50 \%$ was given intravenously as a constant infusion. Termination of the infusion was aimed to coincide with the peak blood glucose concentration reached during the OGTT in the same individual. The individual variation in time from start of the OGTT until peak blood glucose concentration was reached explains the variation of glucose concentration in the infused solution. Blood samples were drawn from the contralateral arm at intervals as during the OGTT. The infusion test described here has been evaluated in detail elsewhere [8].

\section{Laboratory Analysis}

Blood glucose concentrations were measured with a glucose oxidase method. Serum insulin and gastrin concentrations were measured radioimmunochemically. The insulin antiserum used binds insulin and proinsulin with equimolar potency [7]. The gastrin antiserum used binds component I, II (gastrin-34) and III (gastrin-17) also with equimolar potency, while the binding of component IV (gastrin-14) is only $60 \%$ of that of the larger molecular forms of gastrin [11]. Detection limit, precision, accuracy and specificity of the assays have been described in detail elsewhere [7]. The data are presented as mean \pm SEM. The significance of differences between means was evaluated by Student's t-test. Differences resulting in P-values less than 0.05 were considered significant. The insulinogenic index was calculated by dividing the incremental area below the insulin concentration curve by the incremental area under the glucose concentration curve.

\section{Results}

Blood glucose concentrations in the patients were almost identical during OGTT and IVGI (Fig. 1).
Also controls displayed closely identical blood glucose concentrations in the two tests (Fig. 2). In the patients blood glucose concentrations were significantly lower than those in controls both in the fasting state (Table 1) and during both tests (Figs. 1 and 2).

Serum insulin concentrations in the patients during the OGTT and IVGI were almost identical to the corresponding concentrations in the controls. The insulinogenic index during OGTT was $1.5 \pm 0.3$ in patients and $0.5 \pm 0.1$ in controls. During IVGI the insulinogenic index was $0.7 \pm 0.2$ in patients and 0.3 \pm 0.1 in controls. Differences in insulinogenic indices between patients and controls were significant.

Serum gastrin concentrations in the fasting state were identical in patients and controls. Ten minutes after ingestion of glucose the patients displayed a small, but significant increase in gastrin concentrations (Fig. 1). In the normal subjects serum gastrin concentrations did not increase significantly after oral glucose. After intravenous glucose infusion serum gastrin concentrations remained constant in both groups (Figs. 1 and 2).

\section{Discussion}

The present study has shown that blood glucose concentrations decrease markedly after jejuno-ileostomy. The glucose concentrations were decreased not only below the preoperative levels in the same individuals, but also below the concentrations found in 


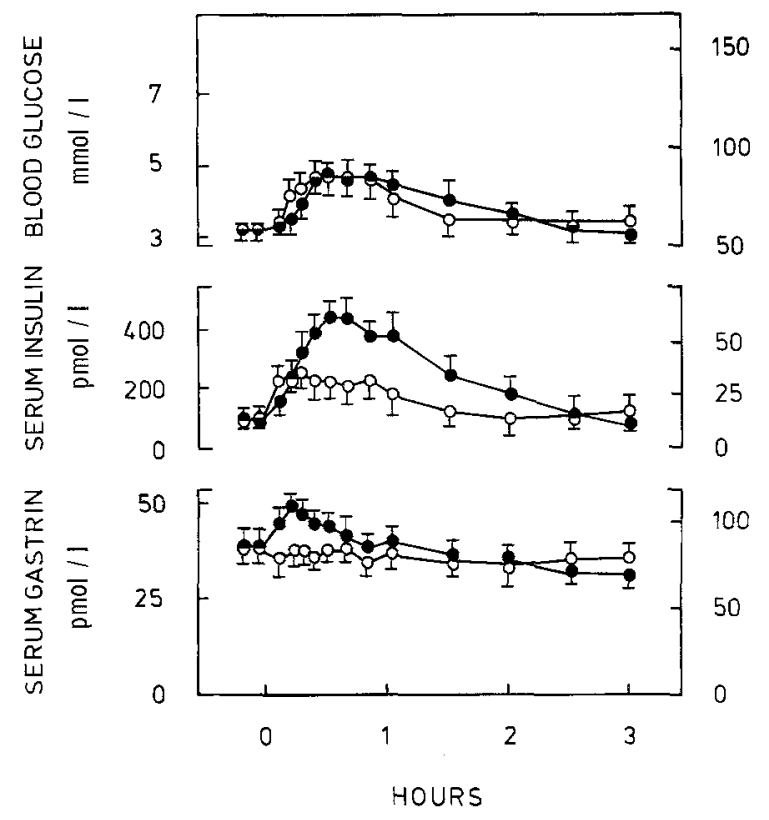

Fig. 1. Blood glucose, serum insulin and serum gastrin concentrations during a $50 \mathrm{~g}$ oral glucose tolerance test (-_ _ and a $16.7 \mathrm{~g}$ intravenous glucose infusion test $(\mathrm{O}-\mathrm{O})$ in nine patients after jejuno-ileostomy for obesity

normal non-obese subjects. The data indicate that the disposal of glucose from blood to tissue increases after jejuno-ileostomy, since glucose concentrations were low after both enteral and intravenous glucose administration. Thus the poor rise in glucose concentrations after parenteral glucose infusion in combination with the decreased basal glucose concentrations cannot be explained by deficient enteral absorption of glucose. Notably, no patients had glucosuria after the bypass operation.

In contrast, insulin and gastrin concentrations deviated only slightly from normal after jejuno-ileostomy. The ratios of insulinogenic indices from oral and intravenous glucose loads $(1.5 / 0.7=2$ in patients and $0.5 / 0.3=1.7$ in controls) confirm that the incretin effect was well preserved in the patients in spite of exclusion of the majority of the gut [13]. However, a comparison of the ratio of insulinogenic indices of the patients and the controls from the same type of glucose challenge $(1.5 / 0.5=3$ for the oral load and $0.7 / 0.3=2.5$ for the intravenous load) shows that the B-cell sensitivity to glucose is increased in these patients. The abnormality of the bypassed patients therefore consists of two factors, an increased B-cell sensitivity to glucose, and increased capacity for peripheral glucose disposal, in spite of unchanged insulin concentrations. The increased glucose disposal is illustrated by the

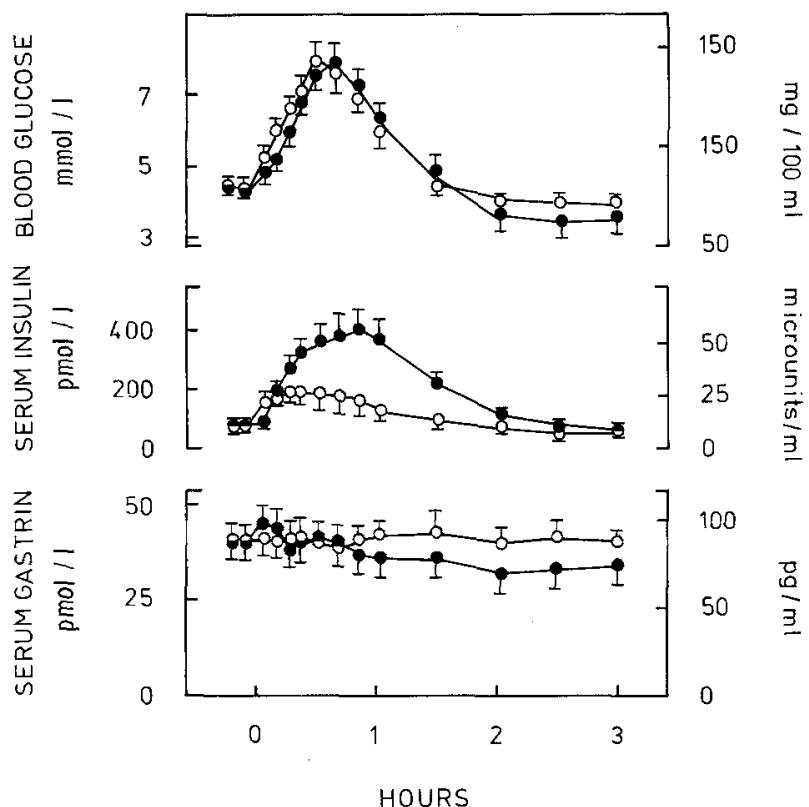

Fig. 2. Blood glucose, serum insulin and serum gastrin concentrations during a $50 \mathrm{~g}$ oral glucose tolerance test (-_and a $16.7 \mathrm{~g}$ intravenous glucose infusion test $(\mathrm{O}-\mathrm{O})$ in nine matched controls

increase of the mean glucose elimination constant $(\mathrm{K}$ $\left.=\frac{\ln 2 \times 100}{t_{1 / 2}}\right)$ from 0.92 before operation to 1.44 after jejuno-ileostomy [13].

The insulin concentrations in the patients cannot explain the increased glucose disposal. If so, unoperated obese patients should suffer from hypoglycaemia due to their well known hyperinsulinaemia [5, $13,14]$, but on the contrary obesity is accompanied by hyperglycaemia and a high frequency of diabetes mellitus $[5,13,14]$. It is also unlikely that intestinal bypass increases the biological activity of circulating insulin molecules. The only way to induce such an effect is by reduction of proinsulin and intermediate molecular forms, which are biologically less active than the insulin molecule itself. However, proinsulin and intermediate forms constitute only a small fraction (5-10 per cent) of the insulin immunoreactivity in serum both in obese and non-obese persons [15, 16].

The small gastrin response to oral glucose in the by-passed patients does not contribute to the increased glucose disposal, since gastrin has a diabetogenic effect on glucose metabolism $[7,9,11]$. The mechanism behind the increased gastrin concentration in bypassed patients is, in all likelihood, removal of the normal intestinal inhibitor of gastrin secretion $[7,8,11]$. 
While the increased insulin-like-activity in bypassed patients is hardly explained by abnormalities in the circulating insulins and gastrins, a number of other mechanisms - acting alone or in combination might be responsible, although the present data give no clues as to which. The possible mechanisms include 1) increased number and/or affinity of peripheral insulin receptors [17]; 2) increased concentration of insulin-like growth factors (NSILAs) $[18]$; 3) decreased concentrations of known insulin antagonists, like epinephrine, cortisol and pancreatic glucagon; and finally 4) increased concentrations of hormones that counteract the action of insulin antagonists. With respect to the last possibility hypersecretion of enteroglucagon might well be responsible. Thus, enteroglucagon circulates in greatly enhanced concentrations both in the fasting state and after food in bypassed patients [19, and Holst, J. J. \& Sørensen, T, unpublished studies]. Enteroglucagon binds to the hepatic glucagon receptor $[20,21]$, thereby probably inhibiting the binding of pancreatic glucagon. Increased concentrations of enteroglucagon may consequently decrease the glycogenolytic effect of pancreatic glucagon, and induce hypoglycaemia, as we found in patients with reactive hypoglycaemia [22, 23].

Whatever the mechanism the increase in glucose disposal after intestinal bypass is of considerable clinical significance. It may explain why most bypassed obese patients, in spite of great initial weight loss, never reach normal weight.

Acknowledgement. The present study was supported by a grant from the Danish Medical Research Council (J. nr. 512-1048).

\section{References}

1. McIntyre, N., Holdsworth, C. D., Turner, D. S.: New interpretation of oral glucose tolerance. Lancet 1964 II, 20-21

2. Elrick, H., Stimmler, L., Hlad, C. J., Jr., Arai, Y.: Plasma insulin response to oral and intravenous glucose administration. $J$. Clin. Endocrinol. Metab. 24, 1076-1082 (1964)

3. Zunz, E., La Barre, J.: Contributions a l'etude des variations physiologiques de la secretion interne du pancreas: relations entre les secretions externe et interne du pancréas. Arch. Int. Physiol. Biochim. 31, 20-44 (1929)

4. Unger, R.H., Eisentraut, A. M.: Enteroinsular axis. Arch. Intern. Med. 123, 261-266 (1969)

5. Perley, M. J., Kipnis, D. M.: Plasma insulin responses to oral and intravenous glucose: Studies in normal and diabetic subjects. J. Clin. Invest. 46, 1954-1962 (1967)

6. Rehfeld, J. F.: Effect of gastrin and its C-terminal tetrapeptide on insulin secretion in man. Acta Endocrinol. (Kbh.) 66, 169-176 (1971)
7. Rehfeld, J. F., Stadil, F.: The effect of gastrin on basal- and glucose-stimulated insulin secretion in man. J. Clin. Invest. 52, 1415-1426 (1973)

8. Rehfeld, J. F., Stadil, F.: The glucose-induced gastrointestinal stimulation of insulin secretion in man: relation to age and to gastrin release. Eur. J. Clin. Invest. 5, 273-283 (1975)

9. Rehfeld, J. F., Holst, J. J., Kühl, C.: The effect of gastrin on basal and amino acid-stimulated insulin and glucagon secretion in man. Eur. J. Clin. Invest. 8, 5-9 (1978)

10. Rehfeld, J. F., Stadil, F., Baden, H., Fishermann, K.: The enteral insulin-stimulation after Whipple's operation. Diabetologia 11, 207-210 (1975)

11. Rehfeld, J.F.: Disturbed islet-cell function related to endogenous gastrin release: Studies on insulin secretion and glucose tolerance in pernicious anemia. J. Clin. Invest. 58, 41-49 (1976)

12. Rehfeld, J. F., Lauritsen, K. B., Stadil, F.: Insulin secretion in the Zollinger-Ellison syndrome. Scand. J. Gastroenterol. 11 (Suppl. 37), 63-66 (1976)

13. Rehfeld, J. F., Juhl, E., Quaade, F.: Effect on insulin and glucose metabolism of jejuno-ileostomy in ten obese subjects. Metabolism 19, 529-538 (1970)

14. Karam, J. H., Grodsky, G. M., Forsham, P. H.: Excessive insulin response to glucose in obese subjects as measured by immunoassay. Diabetes 12, 196-204 (1963)

15. Rubinstein, A. H., Block, N. B., Starr, J., Melani, F., Steiner, D. F.: Proinsulin and C-peptide in blood. Diabetes 21 (Suppl. 2), 661-672 (1972)

16. Duckworth, W. C., Kitabchi, A. E.: Direct measurement of plasma proinsulin in normal and diabetic subjects. Am. J. Med. 53, 418-427 (1972)

17. Olefsky, J. M.: The insulin receptor: its role in insulin resistance of obesity and diabetes. Diabetes 25, 1154-1162 (1976)

18. Zapf, J., Schoenle, E., Froesch, E. R.: Insulin-like growth factors I and II: Some biological actions and receptor binding characteristics of two purified constituents of nonsuppressible insulin-like activity of human serum. Eur. J. Biochem. 87, 285-296 (1978)

19. Barry, R. E., Barisch, J., Bray, G. A., Sperling, M. A., Morin, R. J., Benfield, J.: Intestinal adaption after jejunoileal bypass in man. Am. J. Clin. Nutr. 30, 32-42 (1977)

20. Holst, J. J.: Extraction, gel filtration pattern, and receptor binding of porcine gastrointestinal glucagon-like immunoreactivity. Diabetologia 13, 159-169 (1977)

21. Holst, J. J., Rehfeld, J. F.: Human circulating gut glucagon: Binding to liver cell plasma membranes. In: Gastrointestinal Hormones. Thompson, J.C. (Ed.), pp. 529-536. Austin \& London: University of Texas Press 1975

22. Rehfeld, J. F., Heding, L. G.: Increased gut glucagon release in reactive hypoglycaemia. $\mathrm{Br}$. Med. J. 1970 II, 706-707

23. Rehfeld, J. F., Heding, L. G., Holst, J. J.: Increased release of gut glucagon as pathogenetic factor in reactive hypoglycaemia. Lancet 1973 I, 116-118

Received: April 16, 1978,

and in revised form: August 21, 1978

Dr. J. F. Rehfeld

Institute of Medical Biochemistry

University of Aarhus

DK-8000 Aarhus C

Denmark 